\title{
Kierunki racjonalizacji struktury rolnictwa polskiego w świetle rozwiazań stosowanych w Europie Zachodniej
}

\section{$\mathbf{R}$} olnictwo polskie w dalszym ciagu znacznie odbiega od krajów zachodnioeuropejskich. Dysproporcja w zakresie stopnia zaawansowania rozwoju szczególnie widoczna jest na poziomie struktury agrarnej. Ta z kolei w znacznym stopniu determinuje poziom opłacalności produkcji rolnej i tym samym poziom konkurencyjności na wspólnotowym rynku. W latach 1980-2007 odnotowano w Polsce spadek ogólnej liczby gospodarstw o niespełna $25 \%$, co stanowiło 586 tys. jednostek. W tym samym czasie w państwach, z którymi Polska konkuruje z uwagi na profil produkcji rolnej, zmiany te były nieporównywalnie większe. W Danii liczna gospodarstw zmniejszyła się aż o 63\%, we Francji o 58\%, a w Niemczech o 56\%. Różnice te są jeszcze wyraźniejsze jeżeli dokona się zestawienia średniego obszaru gospodarstw, który w Danii wynosi 60 ha, we Francji 55,7 ha, a u naszych zachodnich sąsiadów 48,4 ha. W Polsce natomiast plasuje się on na poziomie $12,3 \mathrm{ha}^{1}$. Dane te wyraźnie wskazują na poważne w tym obszarze zapóźnienie Polski, a tym samym stanowią ważną przesłankę konieczności podejmowania zaplanowanych i długofalowych działań zmierzających do racjonalizacji struktury agrarnej polskiego rolnictwa.

Kwestia przemian strukturalnych w latach 60 . stała się przedmiotem zainteresowania rządów w krajach Europy Zachodniej. W polityce interwencyjnej zaczęto stosować różnorodne środki zmierzające do stworzenia racjonalnej struktury ekonomicznej rolnictwa. Zapoczątkowany wówczas nurt aktywnej polityki państwa w celu kształtowania struktury rolnej zyskiwał w kolejnych latach na znaczeniu. Obecnie jest on kontynuowany nie tylko na poziomie poszczególnych krajów, ale także obejmuje bardzo rozbudowane mechanizmy Wspólnej Polityki Rolnej w ramach Unii Europejskiej, których celem jest stymulowanie korzystnych przemian strukturalnych oraz wypracowanie wspólnego, racjonalnego modelu rolnictwa.

\section{Ksztaltowanie struktury agrarnej w krajach UE}

Podstawą struktury rolnictwa krajów Europy Zachodniej jest gospodarstwo rodzinne². Niemniej jednak należy zauważyć, iż normy wyznaczające kryteria takich jednostek w pra-

\footnotetext{
${ }^{1}$ Dotyczy powierzchni ogólnej gospodarstwa, do której zaliczono użytki rolne, trwałe pastwiska, trwałe uprawy oraz ogródki przydomowe, stąd też dane te różnią się od statystyk krajowych GUS, wedle których w 2007 r. w Polsce średnia powierzchnia gruntów w gospodarstwie wynosiła 7,24 ha, w tym 6,27 ha użytków rolnych. Por.: Farm structure - 1999/2000 survey, EUROSTAT, European Communities, Luxemburg 2003; Farm structure. Historical results - Surveys from 1966/67 to 1997. Final version: October 2000, EUROSTAT, European Communities, Luxemburg 2000, EUROSTAT, Number of agricultural holdings - [tag00001], data sporządzenia: 1.07.2010.

${ }^{2}$ W Unii Europejskiej obowiązuje pojęcie gospodarstwa rozwojowego, które w myśl przepisów powinno być głównym źródłem utrzymania rodziny. Ponadto prowadząca je osoba musi posiadać odpowiednie kwalifikacje rolni-
} 
wodawstwach poszczególnych krajów wskazane są na różnym poziomie legislacyjnym. Rozpiętość zastosowanych środków prawnych jest szeroka, poczynając od państw gwarantujących konstytucyjną ochronę dla gospodarstw rodzinnych, poprzez przepisy pośrednio dotyczące struktury rolnictwa, a kończąc na konstytucjach, które pomijają problem określenia podstaw ustroju rolnego danego państwa. W państwach członkowskich Unii Europejskiej stosuje się różne rozwiązania prawne dotyczące stopnia interwencji w obrót gruntami rolnymi mające na celu ochronę i poprawę struktury agrarnej gospodarstw rodzinnych. Całkowity zakaz sprzedaży gruntów rolnych stosowany jest rzadko i tylko w określonych sytuacjach, a mianowicie dotyczy terenów strategicznych, położonych najczęściej w strefach nadgranicznych. Często zaś stosowanym w krajach unijnych ograniczeniem jest zakaz sprzedaży gruntów na cele inne niż wynikające z planu zagospodarowania przestrzennego danego obszaru. Wprowadza się też inne ograniczenia w zakresie obrotu gruntami rolnymi np. wymóg posiadania przez potencjalnego nabywcę odpowiednich kwalifikacji rolniczych (wykształcenia) lub przewidzianego $\mathrm{w}$ przepisach stażu pracy w gospodarstwie rolnym, zamieszkania na terenie jednostki administracyjnej, w obrębie której znajduje się nabywany grunt lub na terenie posiadanego i użytkowanego gospodarstwa, zastrzeżenie osobistej pracy lub zarządzania nabywanym gospodarstwem, czy też czasowy zakaz zbycia nieruchomości nabytej za Skarbu Państwa lub gruntu pozyskanego w drodze przywrócenia (restytucji) ${ }^{3}$. Ze stosowanych rozwiązań wyróżnić należy:

- ograniczenia w swobodzie obrotu nieruchomościami rolnymi chroniące gospodarstwa rodzinne przed nieracjonalnymi podziałami;

— stosowanie zasad niepodzielności gospodarstw rodzinnych w postępowaniu spadkowym;

- zakaz podziału gospodarstw utworzonych w wyniku kompleksowych prac urządzeniowo-rolnych dokonanych na koszt państwa;

- stosowanie szeregu dodatkowych mechanizmów ochronnych, np. obligatoryjne tworzenie przez współspadkobierców rodzinnych spółek mających na celu ochronę osoby przejmującej gospodarstwo przed nadmiernymi obciążeniami z tytułu spłat ${ }^{4}$.

Działalność państwa zmierzającą do ukształtowania racjonalnej struktury obszarowej w rolnictwie prześledzimy na przykładzie trzech państw, a mianowicie: Francji, Niemiec i Danii. Taki wybór podyktowany jest faktem, iż kraje te odniosły wyraźne sukcesy w kształtowaniu struktury agrarnej.

Najwyższy poziom legislacyjny oraz odpowiadający mu najskuteczniejszy model instytucjonalny wpływający na kształtowanie struktury obszarowej ma miejsce we Francji ${ }^{5}$. Model ten opiera się na działalności Spółek Urządzeń i Osadnictwa Rolnego (SAFER) ${ }^{6}$. Przepisy

cze i zobowiązana jest do prowadzenia rachunkowości rolnej. Dla gospodarstwa takiego musi być także stworzony plan rozwoju na co najmniej 6 lat oraz dochód z pracy w rolnictwie winien być niższy niż ten określany przez dane państwa członkowskie jako właściwy po modernizacji. Por. dyrektywa Rady nr L 159 z 17 kwietnia 1972 r. (tzw. dyrektywa „modernizacyjna”), Dz. U. W. E. L 96 z 23 kwietnia 1972 r., której zasadnicze postanowienia zostały utrzymane przez później wydane akty łącznie z art. 5 rozporządzenia Rady nr 1257 z 17 maja 1999 r., Dz. U. W. E. nr L 160 z 26 czerwca 1999 r.

${ }^{3}$ D. Stojak, Niekonstytucyjne wpisy blokujq obrót ziemia, ,Dziennik Gazeta Prawna”, nr 131 (2762), 8 lipca 2010 r., s. B7.

${ }^{4}$ A. Kołodziej, Unia Europejska. Ewolucja polityki strukturalnej, ,Agroprzemiany” 2002, nr 3.

${ }^{5}$ A. Lichorowicz, W kwestii modelu prawnego instytucji ksztaltujacych struktury gruntowe w rolnictwie (studium prawno-porównawcze), w: S. Prutis (red.), „Studia Iuridica Agraria”, tom V, Temida 2, Białystok 2005, s. 135.

${ }^{6}$ SAFER powstały na podstawie ustawy z dnia 5 sierpnia $1960 \mathrm{r}$. 
francuskie wprost podkreślają, że celem SAFER jest m.in. rozwój, powiększanie oraz ochrona gospodarstw rodzinnych ${ }^{7}$. Spółki te posiadają zasięg lokalny, a formą prawną ich funkcjonowania jest spółka cywilna. Do zadań SAFER należy także utrzymywanie równowagi popytu i podaży w obrocie ziemią rolniczą, komasacja gruntów, decyzje w zakresie wykorzystania ziemi w celach pozarolniczych, zarządzanie gruntami leśnymi, ochrona środowiska naturalnego oraz pomoc w tworzeniu nowych jednostek produkcyjnych. SAFER ma również możliwość wydzierżawiania gospodarstwa na okres 1-6 lat (z możliwością przedłużenia) oraz może skorzystać z prawa pierwokupu. Ponadto sprawuje kontrolę nad obrotem ziemią rolniczą o powierzchni od 0,1 do 1 ha w zależności od regionu ${ }^{8}$. Sprzedaż gruntu może dojść do skutku tylko wówczas, gdy Spółka Urządzeń i Osadnictwa Rolnego w ciągu dwóch miesięcy od daty poinformowania o zamiarze transakcji przez biuro notarialne, nie zgłosi zamiaru skorzystania z prawa pierwokupu danej nieruchomości. SAFER interweniuje wówczas, gdy sprzedawane gospodarstwo rolne zamierza zakupić osoba nie zajmująca się rolnictwem lub w wyniku transakcji straciłoby rodzinny charakter. Spółka może działać w oparciu o prawo pierwokupu także w celu poprawy struktury agrarnej gospodarstw w regionie, pomocy w zakładaniu gospodarstw rolnych przez młodych rolników, zapewnienia równowagi między gospodarstwami indywidualnymi a przedsiębiorstwami użyteczności publicznej, przeciwdziałania spekulacji, zachowania walorów krajobrazowych czy też zalesiania ${ }^{9}$. Prawo to podlega jednak pewnym ograniczeniom; SAFER nie może z niego skorzystać, jeżeli doprowadziłoby to do likwidacji gospodarstwa powyżej 1 SMI lub zmniejszenia jego powierzchni poniżej $1 \mathrm{SMI}^{10}$. Przepisy te mają na celu ochronę gospodarstw rodzinnych przed nadmierną ingerencją administracyjną ${ }^{11}$. Na wykupionych gruntach spółki mają prawo dokonywania prac podnoszących wartość ziemi (np. melioracja czy wyrównywanie ziemi). Ziemia ta jest wykorzystywana do tworzenia nowych lub powiększania istniejących już gospodarstw rolnych o charakterze rodzinnym ${ }^{12}$. Przeznacza się ją również na budowę linii kolejowych czy autostrad. Grunty z zasobu SAFER może zakupić tylko osoba posiadająca odpowiednie wykształcenia i praktykę zawodową w rolnictwie. Kandydaci na zakup ziemi poddawani są ocenie, a sama transakcja może dojść do skutku po przeprowadzeniu publicznego przetargu. Niezwykle ciekawym rozwiązaniem z punktu widzenia kształtowania struktury obszarowej gospodarstw, jest uprzywilejowana pozycja mniejszych gospodarstw rodzinnych nie zaspokajających w wystarczającym stopniu potrzeb rodziny właściciela. Jeżeli takie gospodarstwo sąsiaduje ze zbywanymi z zasobu SAFER nieruchomościami, a jego właściciel zainteresowany jest ich kupnem, ma on pierwszeństwo, a jego kandydatura jest w zasadzie zwolniona z ko-

\footnotetext{
${ }^{7}$ Art. 143-2 francuskiego kodeksu rolnego (Code Rural).

${ }^{8}$ D. Stankiewicz, Ograniczenia w obrocie gruntami rolnymi w wybranych krajach Unii Europejskiej w aspekcie prac nad stosownymi zmianami w ustawodawstwie polskim, Kancelaria Sejmu, Biuro Studiów i Ekspertyz, Informacja nr 886, luty 2002 r., s. 7.

${ }^{9}$ Francja. Informator gospodarczy, Ministerstwo Gospodarki, Pracy i Polityki Społecznej, Paryż 2003, s. 79.

${ }^{10}$ Jednostka SMI stanowi we Francji krajową normę odnoszącą się do gospodarstw rolnych. Pierwotnie wielkość SMI określano według odgórnie przyjętych kryteriów obszarowych, tzn. 1 SMI był równy 25 ha, przy zastrzeżeniu, że możliwe były pewne regionalne odstępstwa od tej powierzchni. Jednak ustawą z dnia 9 lipca 1999 r. treść tego pojęcia została zmieniona i oznacza powierzchnię gospodarstwa, która zapewnia zatrudnienie dwóm osobom pracującym w pełnym wymiarze.

${ }^{11}$ Mimo, iż kompetencje SAFER są rozległe, to jednak zadaniem przepisów regulujących obrót gruntami rolnymi jest popieranie i ułatwianie przekazywania gospodarstwa w obrębie rodziny (art. L 330-1 Code Rural).

${ }^{12}$ Powiększane za sprawą działalności SAFER gospodarstwo, powinno zachować rodzinny charakter. Art. 2 ust. 7 ustawy z dnia 29 grudnia 1977 r. zastrzega, że powiększane gospodarstwo nie powinno przekraczać 4 SMI.
} 
nieczności uczestniczenia $\mathrm{w}$ przetargu publicznym ${ }^{13}$. Ponadto pierwszeństwo do nabycia gospodarstwa mają w szczególności:

- rolnicy wywłaszczeni;

— młodzi rolnicy zamierzający założyć własne gospodarstwo rolne;

- rolnicy pełniący obowiązki pomocnika, (,pomocnik rodzinny” to krewny lub spowinowacony z właścicielem gospodarstwa lub jego małżonkiem, który ma ukończone co najmniej 16 lat, zamieszkuje na terenie gospodarstwa i bierze czynny udział w pracach gospodarskich, nie może to jednak wynikać z umowy o pracę; prawo, poza nieodpłatnym utrzymaniem w gospodarstwie, nie gwarantuje mu żadnego uposażenia pieniężnego, które wynikać jednak może z woli stron);

— rolnicy będący wspólnikiem w gospodarstwie rodzinnym (,wspólnik w prowadzeniu gospodarstwa" również musi być spokrewniony z właścicielem gospodarstwa, a ponadto mieć ukończone co najmniej 18 lat, gospodarstwo powinno być jego podstawowym miejscem zatrudnienia, dochody z niego czerpane nie muszą jednak stanowić głównego źródła utrzymania wspólnika; praca nie może wynikać ze stosunku pracy czy też innej formy spółki cywilnej lub handlowej z prowadzącym gospodarstwo);

— rolnicy, którzy utracili gospodarstwa, w wyniku działów spadkowych lub zakończenia dzierżawy, na których dotychczas pracowali (ustawodawstwo francuskie daje możliwość narzucenia niepodzielności gospodarstwa rodzinnego w postępowaniu spadkowym; w celu zabezpieczenia rolnika przejmującego niepodzielone gospodarstwo, wprowadzono możliwość rozłożenia potencjalnych spłat na raty lub też uzyskania dotacji do kredytów zaciągniętych z tym przeznaczeniem) $)^{14}$.

Wszyscy rolnicy zainteresowani zakupem gospodarstwa muszą udowodnić posiadanie odpowiednich kwalifikacji rolniczych (dyplom lub zaświadczenie o pracy w gospodarstwie rolnym). Inny potencjalny nabywca, niespełniający powyższych wymogów uprawniających do pierwszeństwa, może nabyć nieruchomość, pod warunkiem że wcześniej nie zgłosi się osoba w tym zakresie uprzywilejowana. Kupujący gospodarstwo rolne musi spełnić następujące kryteria:

— wyższe lub średnie wykształcenie rolnicze;

- co najmniej 5 lat pracy w gospodarstwie w ciagu ostatnich 15 lat;

- 3-letni staż pracy w gospodarstwie rolnym w przypadku ukończenia wyższej uczelni rolniczej;

— dowód z Urzędu Podatkowego o dochodzie netto z działalności pozarolniczej, jeżeli osoba ma wiele zawodów ${ }^{15}$.

Nabywca musi zobowiązać się również do co najmniej 15-letniego osobistego prowadzenia zakupionego gospodarstwa, w tym osobistego wykonywania całości lub części prac związanych z działalnością rolniczą. Ponadto w tym czasie nie ma prawa wydzierżawić gospodarstwa lub oddać w użytkowanie, może natomiast przekazać je zstępnym lub jego małżonkom. Sprzedaż zaś części gospodarstwa rodzinnego może mieć miejsce tylko w wyjątkowych sytuacjach i wymaga zgody SAFER. Obwarowania te stanowią swego rodzaju parasol ochronny nad nowopowstałymi gospodarstwami rodzinnymi ${ }^{16}$.

\footnotetext{
${ }^{13}$ A. Lichorowicz, Status prawny gospodarstw rodzinnych w ustawodawstwie krajów Europy Zachodniej, Wydawnictwo Temida 2, Białystok 2000, s. 73.

${ }^{14}$ Ibidem, s. 48-73.

15 D. Stankiewicz, Ograniczenia w obrocie gruntami rolnymi..., op. cit., s. 7.

${ }^{16}$ A. Lichorowicz, W kwestii modelu prawnego..., op. cit., s. 137.
} 
Ochronie gospodarstw rodzinnych służą także przepisy zapobiegające nadmiernej koncentracji gruntów rolnych będących we władaniu jednego rolnika. Powstawanie dużych jednostek kosztem gospodarstw rodzinnych posiadających mniejsze zasoby finansowe, zostało poddane kontroli. Transakcje skutkujące powiększeniem gospodarstwa powyżej normy $0,5-1,5$ obszarowej jednostki odniesienia (UR) ${ }^{17}$ wymagają uzyskania zgody administracyjnej ${ }^{18}$.

Obywatele Unii Europejskiej w zakresie obrotu gruntami rolnymi we Francji, podlegają tym samym przepisom co Francuzi. Jeżeli zaś chodzi o cudzoziemców z państw spoza Wspólnoty (również państw kandydackich), obowiązuje zasada, iż osoby/spółki pragnące nabyć ziemię, muszą mieć uregulowany status prawny, co jest równoznaczne z co najmniej dziesięcioletnim zezwoleniem na pobyt. Poza tym muszą spełniać oczywiście wszystkie wyżej wymienione warunki ${ }^{19}$.

Podobnie jak we Francji, także w Niemczech kwestie przeniesienia prawa własności ziemi rolniczej podlegają kontroli ${ }^{20}$, którą sprawuje państwo za pośrednictwem stowarzyszeń ziemskich. Głównym ich udziałowcem jest administracja rządowa poszczególnych landów. Nadzór zaś nad spółkami sprawuje Federalne Ministerstwo Rolnictwa. Odmowę zgody na zakup ziemi może wydać organ administracyjny w przypadku, gdy transakcja przyczyniłaby się do powstania „nieracjonalnej konfiguracji gruntów”, za którą uważa się:

- nadmierną koncentrację gruntów, szczególnie w sytuacji, gdy posiadane już przez danego nabywcę nieruchomości stanowią wystarczającą podstawę egzystencji jego i rodziny;

— brak posiadania przez nabywcę odpowiednich kwalifikacji rolniczych;

- nabycie ziemi w celach spekulacyjnych tzn. gdy nabywca nie ma zamiaru trwale włączyć zakupionego gruntu do swojego gospodarstwa i użytkować go w celach rolniczych $^{21}$.

Z brakiem zgody na zakup nieruchomości należy się również liczyć, gdy potencjalny nabywca oferuje cenę rażąco nieadekwatną do wartości działki. W celu zapobiegania tego typu spekulacji, jako podstawę określenia wartości gruntu przyjmuje się jego wartość dochodową, nie zaś rynkową. Istotną przesłanką dla decyzji odmownej jest także sytuacja, w której gospodarstwo w wyniku transakcji uległoby nieuzasadnionemu podziałowi lub znacznemu zmniejszeniu, co doprowadziłoby do utraty jego samowystarczalności ${ }^{22}$.

Bardzo interesujące są rozwiązania prawne dotyczące dziedziczenia gospodarstw rolnych, jednoznacznie służące ochronie gospodarstw rodzinnych. Doktryna prawa niemieckiego nie przewiduje dzielenia gospodarstw w trakcie dziedziczenia (zasada niepodzielnego dziedziczenia). Rozwiązania w tym zakresie wskazują również wyraźnie na preferowanie spadkobierców pracujących w rolnictwie i posiadających odpowiednie kwalifikacje rolnicze, zapewniając im korzystne warunki spłat pozostałych spadkobierców. Warto jednak zauważyć, że szczegółowe wytyczne w tym obszarze regulowane są przez akty prawne posz-

\footnotetext{
${ }^{17}$ Pojęcie obszarowej jednostki odniesienia - UR wprowadzone zostało ustawą z dnia 9 lipca 1999 r. i odpowiada powierzchni zapewniającej ekonomiczną żywotność gospodarstwa. Patrz szerzej: A. Lichorowicz, Status prawny gospodarstw rodzinnych..., op. cit., s. 75-76.

${ }^{18}$ Art. 331-2 Code Rural.

${ }^{19}$ D. Stankiewicz, Ograniczenia w obrocie gruntami rolnymi..., op. cit., s. 7.

${ }^{20}$ Kwestie te reguluje ustawa $\mathrm{z}$ dnia 28 lipca $1961 \mathrm{r}$. o obrocie gruntami rolnymi.

${ }^{21}$ D. Stankiewicz, Ograniczenia w obrocie gruntami rolnymi..., op. cit., s. 9.

${ }^{22}$ Za nieracjonalny podział działki rolnej uznaje się jej zmniejszenie poniżej 1 ha, natomiast w przypadku działki leśnej, granicę stanowi 3,5 ha (paragraf 9 ust. 3 pkt 2 i 3 ustawy z dnia 28 lipca 1961 r.).
} 
czególnych landów, dzięki czemu są zróżnicowane i charakteryzują się lokalnym zakresem obowiązywania $^{23}$.

Kształtowaniem struktury obszarowej w Niemczech zajmują się organizacje niemieckich kółek osadniczych - Landgesselschaften, które mają prawo odkupu ziem, w stosunku do których organ administracyjny odmówił zgody na transakcję szkodliwą strukturalnie. Zadaniem Landgesselschaften jest zakup, użytkowanie i gromadzenie rezerw gruntów, mające na celu poprawę struktury agrarnej. Zgromadzone grunty przeznaczone są na tworzenie nowych lub powiększanie już istniejących gospodarstw rodzinnych. Nabywca zobligowany jest osobiście uprawiać zakupione grunty i mieszkać na terenie tego gospodarstwa. Pod pewnymi warunkami, które szczegółowo regulują przepisy, może jednak sprzedać grunty w całości lub w części małżonkowi, lub innemu członkowi swojej rodziny. W wypadku innych osób, Landgesselschaften ma prawo odkupu nieruchomości ${ }^{24}$.

Interesujące rozwiązania w tej dziedzinie występują także w Danii. Podmiotem zajmującym się kształtowaniem struktury gospodarstw jest działający w ramach Ministerstwa Rolnictwa Królestwa Danii, Departament Struktur ${ }^{25}$. Jest on upoważniony do zakupu gruntów w celu poprawy lokalizacji gospodarstw, powiększenia ich obszaru, zachowania walorów krajobrazu wiejskiego, gromadzenia rezerwy ziemi na odszkodowania za utracone tereny rolnicze oraz na urządzanie terenów zieleni. Departament ma prawo pierwokupu ziemi rolniczej na rzecz państwa w przypadku realizacji wcześniej wymienionych zadań. Sprawuje również nadzór nad regionalnymi bankami ziemi rolniczej gromadzącymi grunty na cele komasacji służącej optymalizacji lokalizacji nowych gospodarstw, które powstały w wyniku likwidacji mniejszych, zalesiania lub prac infrastrukturalnych ${ }^{26}$.

Potencjalny nabywca poza ukończonym 18-tym rokiem życia musi spełniać następujące warunki:

- musi posiadać obywatelstwo duńskie lub;

- obywatelstwo innego państwa Unii Europejskiej i mieć prawo nabycia nieruchomości rolnej w Danii na podstawie przepisów obowiązujących w danym kraju;

- powinien mieć prawo stałego pobytu w Danii i jest zobowiązany do stałego osiedlenia się na zakupionej nieruchomości w ciągu 6 miesięcy od jej nabycia;

— nabywca, współmałżonek lub jego dzieci nie mogą być współwłaścicielami nieruchomości rolniczej w innym kraju w chwili nabywania nieruchomości w Danii (jeżeli takową posiada, musi ją uprzednio sprzedać);

— powinien posiadać odpowiednie, uznane przez Ministerstwo Rolnictwa w Danii kwalifikacje rolnicze;

- nabywca zobligowany jest do samodzielnego zarządzania nabytą nieruchomością ${ }^{27}$.

Zakup nieruchomości poniżej 30 ha wiąże się z koniecznością spełnienia 4 pierwszych warunków. Nabywca ziemi o powierzchni powyżej 30 ha może być, w myśl duńskich przepisów, właścicielem dwóch nieruchomości rolniczych na terenie Danii, działki te nie mogą się jednak znajdować w odległości większej niż $10 \mathrm{~km}$ od miejsca stałego

\footnotetext{
${ }^{23}$ Szczególne zasady dziedziczenia gospodarstw rolnych nie obowiązują w Bawarii i krajach związkowych byłego NRD. Patrz szerzej: A. Lichorowicz, Status prawny gospodarstw rodzinnych ..., op. cit., s. 195-196.

${ }^{24}$ A. Zadura, Ksztaltowanie struktury gospodarstwa w wybranych krajach UE, Biuletyn Informacyjny Ministerstwa Rolnictwa i Rozwoju Wsi oraz Agencji Restrukturyzacji i Modernizacji Rolnictwa, nr 1-2/2008 (118), s. 18.

${ }^{25}$ Obrót nieruchomościami rolnymi regulowany jest ustawą z dnia 24 sierpnia $1994 \mathrm{r}$. o nieruchomościach rolnych.

${ }^{26}$ A. Zadura, Ksztaltowanie struktury gospodarstwa..., op. cit., s. 19.

${ }^{27}$ D. Stankiewicz, Ograniczenia w obrocie gruntami rolnymi..., op. cit., s. 11.
} 
zamieszkania rolnika. Co ciekawe, Dania stosuje większe ograniczenia niż Polska, gdyż łączna powierzchnia nieruchomości rolnych, już po nabyciu dodatkowej nieruchomości, będących własnością lub współwłasnością danego rolnika, nie może przekraczać 70 ha.

Podmiotem sprawującym kontrolę nad obrotem nieruchomości rolnych w Danii jest Ministerstwo Rolnictwa. W uzasadnionych przypadkach dopuszcza się odstępstwo od stosowanych przepisów lub też brak zgody na nabycie nieruchomości. Decyzja odmowna będzie miała miejsce w sytuacji uzasadnionych podejrzeń co do spekulacyjnego charakteru zakupu nieruchomości lub też, gdy zakup taki traktowany jest jako inwestycja kapitału. Wyrażona zgoda traci swą ważność, jeżeli nie jest wykorzystana w ciągu trzech lat od jej wydania. W sytuacji, gdy nieruchomość została nabyta lub jest użytkowana z naruszeniem obowiązujących przepisów, ministerstwo może nakazać właścicielowi jej zbycie, a w przypadku dzierżawy odstapienie od realizacji umowy ${ }^{28}$.

\section{Instrumenty prawne i instytucjonalne doskonalenia struktury agrarnej w Polsce}

Podstawę prawną kształtowania struktury agrarnej w Polsce stanowią dwa zasadnicze akty prawne, tj. ustawa z dnia 19 października 1991 roku o gospodarowaniu nieruchomościami rolnymi Skarbu Państwa ${ }^{29}$ oraz ustawa z 11 kwietnia 2003 roku o kształtowaniu ustroju rolnego ${ }^{30}$. Pierwsza $z$ nich reguluje zasady zarządzania mieniem państwowym przede wszystkim w zakresie nieruchomości rolnych oraz nieruchomości i mienia pozostałego po likwidacji państwowych przedsiębiorstw gospodarki rolnej. Obejmuje ona wyszczególnione już mienie zarządzane przez państwowe jednostki organizacyjne, użytkowane wieczyście przez osoby fizyczne i prawne oraz mienie Państwowego Funduszu Ziemi. W jej dyspozycji znajdują się również nieruchomości rolne przejmowane na rzecz Skarbu Państwa na podstawie decyzji administracyjnej lub też z innego tytułu.

Na mocy ustawy z 1991 r. powołano Agencję Własności Rolnej Skarbu Państwa ${ }^{31}$ będącą państwową osobą prawną, która rozpoczęła swoją działalność w 1992 r. Agencja otrzymała uprawnienia reprezentowania praw własności oraz innych praw rzeczowych w stosunku do objętego w jej władanie mienia Skarbu Państwa. Prawo własności w stosunku do mienia państwowego miała wykonywać odrębna państwowa osoba prawna, jednakże przy zachowaniu przez Skarb Państwa praw do mienia oddanego w gospodarowanie. Ustawa dała również podstawy prawne do utworzenia instytucji Zasobu Własności Rolnej Skarbu Państwa, do którego

\footnotetext{
${ }^{28}$ A. Zadura, Ksztaltowanie struktury gospodarstwa..., op. cit., s. 19.

${ }^{29}$ Ustawa z dnia 19 października 1991 roku o gospodarowaniu nieruchomościami rolnymi Skarbu Państwa (Dz. U. 2007, Nr 231, poz. 1700 t.j.).

${ }^{30}$ Ustawa z dnia 11 kwietnia 2003 r. o kształtowaniu ustroju rolnego (Dz. U. Nr 64, poz. 592).

${ }^{31}$ Podstawowym aktem prawnym regulującym działalność AWRSP była ustawa. Poza nią zasady funkcjonowania Agencji wyznaczały: rozporządzenie Rady Ministrów z dnia 21 stycznia 1992 roku w sprawie zasad i trybu postępowania przy pierwszeństwie nabycia mieszkań wchodzących w skład Zasobu Własności Rolnej Skarbu Państwa (Dz. U. Nr 12, poz. 42); rozporządzenie Ministra Rolnictwa i Gospodarki Żywnościowej z dnia 16 stycznia 1992 roku w sprawie określenia szczegółowego trybu sprzedaży nieruchomości i ich części składowych wchodzących w skład Zasobu Własności Rolnej Skarbu Państwa, warunków rozkładania ceny sprzedaży na raty oraz stawki szacunkowej gruntów (Dz. U. Nr 12, poz. 39); rozporządzenie Ministra Rolnictwa i Gospodarki Żywnościowej z dnia 21 stycznia 1992 roku w sprawie szczegółowego trybu przekazywania w zarząd mienia wchodzącego w skład Zasobu Własności Rolnej Skarbu Państwa (Dz. U. Nr 12, poz. 50); rozporządzenie Prezesa Rady Ministrów z dnia 16 marca 1992 roku w sprawie nadania Statutu Agencji Własności Rolnej Skarbu Państwa (Dz. U. Nr 24, poz. 104).
} 
włączono m.in. nieruchomości dotychczasowego Państwowego Funduszu Ziemi oraz pozostałe nieruchomości rolne, stanowiące własność Skarbu Państwa ${ }^{32}$. A. Zieliński uważa, że ustawa o gospodarowaniu nieruchomościami rolnymi wyznaczyła Agencji trzy podstawowe zadania: przejęcie, restrukturyzację i zagospodarowanie mienia ${ }^{33}$. Ideą przyświecającą jej utworzeniu było odejście od wielopodmiotowości państwowego mienia rolnego w kierunku jednej silnej jednostki o szerokich uprawnieniach władczych i możliwościach realizacyjnych ${ }^{34}$.

Ustawa wyszczególnia zadania Agencji wynikające z polityki państwa. W zakresie jej kompetencji znalazły się działania obejmujące :

— poprawę oraz tworzenie struktury obszarowej gospodarstw rodzinnych;

- tworzenie sprzyjających warunków dla racjonalnego wykorzystania potencjału produkcyjnego Zasobu Własności Rolnej Skarbu Państwa;

- restrukturyzację oraz prywatyzację użytkowanego na cele rolnicze mienia Skarbu Państwa;

— obrót nieruchomościami oraz innymi składnikami mienia Skarbu Państwa przeznaczonymi na cele rolnicze;

- administrowanie przeznaczonymi na cele rolnicze zasobami majątkowymi Skarbu Państwa;

— zabezpieczenie majątku Skarbu Państwa;

- inicjowanie prac urządzeniowo - rolnych na gruntach Skarbu Państwa oraz poparcie w kwestii organizowania na nich prywatnych gospodarstw rolnych.

Mając na uwadze realizowane przez Agencję zadania, w jej działalności można wyodrębnić dwa zasadnicze etapy. Pierwszy dotyczy lat 1991-1995, kiedy to główną jej misją była likwidacja przedsiębiorstw państwowych i sprawne przekazanie gruntów nowym użytkownikom. Do końca 1993 roku, zgodnie z założeniami ustawy z 19 października 1991 roku, zostały zlikwidowane wszystkie PPGR, które miały tym procesem zostać objęte ${ }^{35}$. Decyzja o przekazaniu Agencji nieruchomości PFZ będących w dzierżawie lub bezpośrednio w rękach administracji, leżała w gestii wojewodów. Natomiast gruntów będących przedmiotem zarządu czy użytkowania tyczyły się zupełnie odrębne procedury.

W drugim okresie działalności Agencji, obejmującym lata 1995-2003, podstawowym jej zadaniem stała się kwestia administrowania na znacznym areale gruntów państwowych. Realizowana przez Agencją funkcja repartycyjna, zakończyła się niepowodzeniem, gdyż podstawową formą zagospodarowania stała się dzierżawa będąca jedynie rozwiązaniem czasowym. Nowych właścicieli znalazła zaś tylko niewielka liczba gruntów ${ }^{36}$.

Ze względu na problemy w zagospodarowaniu mienia państwowego, pojawiła się konieczność zmian na poziomie rozwiązań prawnych. Wraz z nimi dokonano przemian w strukturach organizacyjnych, powołując Agencję Nieruchomości Rolnych, która stanowi niejako trzeci okres w rozwoju Agencji Własności Rolnej Skarbu Państwa.

${ }^{32}$ M. Możdżeń-Marcinkowski, Agencja Nieruchomości Rolnych, Kantor Wydawniczy Zakamycze, Zakamycze 2003, s. 33-34.

${ }^{33}$ A. Zieliński, Refleksje nad prywatyzacja rolnictwa, [w:] Gospodarka, administracja, samorzqd, red. H. Olszewski, B. Popowska, Poznań 1997, s. 572 i n.

${ }^{34}$ M. Możdżeń-Marcinkowski, Agencja Nieruchomości Rolnych..., op. cit., s. 60.

${ }^{35}$ Do 1993 roku, wojewodowie oraz minister rolnictwa i gospodarki żywnościowej, podjęli decyzję o likwidacji 1595 PPGR. W stosunku do 15 przedsiębiorstw, proces likwidacji rozpoczął się jeszcze przed powołaniem Agencji, zaś kolejnych 38 zastało poddanych odrębnym procesom upadłościowym.

${ }^{36}$ A. Lichorowicz, $W$ kwestii modelu prawnego ..., op. cit., s. 137-140. 
Agencja Nieruchomości Rolnych została powołana na mocy ustawy z dnia 11 kwietnia 2003 roku o kształtowaniu ustroju rolnego. Pod względem prawnym stała się następcą i kontynuatorką Agencji Własności Rolnej Skarbu Państwa, zyskała jednak wówczas nową nazwę i poszerzono zakres jej działań. Oprócz realizowanych uprzednio przez AWRSP zadań, otrzymała nowe, związane z aktywnym działaniem w sferze prywatnego obrotu gruntami rolnymi oraz w zakresie poprawy struktury agrarnej. W głównej mierze ma ona chronić i wzmacniać pozycję gospodarstw rodzinnych, zapobiegać nadmiernej koncentracji gruntów rolnych oraz zapewnić odpowiednie kwalifikacje osób pracujących w gospodarstwach rolnych.

Wspomniane już wcześniej mienie Skarbu Państwa tworzy Zasób Własności Rolnej Skarbu Państwa ${ }^{37}$, którym Agencja gospodaruje poprzez jego sprzedaż, oddanie na czas określony do odpłatnego korzystania osobom prawnym lub fizycznym, wniesienie do spółki, administrowanie, przekazanie w zarząd lub też zamianę nieruchomości. ANR ma też możliwość nieodpłatnego przekazania określonych gruntów ${ }^{38}$. Sprzedaż i nabywanie nieruchomości Zasobu prowadzi Agencja lub inny upoważniony przez nią do tego podmiot. Ustawa dopuszczała możliwość sprzedaży nieruchomości rolnej, jeżeli w jej wyniku łączna powierzchnia użytków rolnych będących własnością danego nabywcy nie przekroczy 500 ha. Pierwszeństwo nabycia nieruchomości z Zasobu przysługuje w kolejności:

— byłemu właścicielowi zbywanej nieruchomości lub jego spadkobiercom;

— spółdzielni produkcji rolnej władającej faktycznie zbywaną nieruchomością;

— dzierżawcy zbywanej nieruchomości, jeżeli dzierżawa faktycznie trwała przez okres co najmniej trzech lat;

- zarządzającemu specjalną strefą ekonomiczną w odniesieniu do nieruchomości położonych w granicach specjalnych stref ekonomicznych ${ }^{39}$.

${ }^{37}$ W kwestii finansów Agencja prowadzi odrębną gospodarkę dla siebie oraz odrębną dla Zasobu Własności Rolnej Skarbu Państwa. Roczne plany finansowe sporządzane osobno dla ANR i Zasobu zatwierdza minister właściwy do spraw rozwoju wsi w porozumieniu z właściwym ministrem do spraw Skarbu Państwa. Drogą odrębnego rozporządzenia określają też oni szczegółowe zasady gospodarki finansowej ANR. Środki finansowe uzyskiwane z gospodarowania mieniem Zasobu, przeznaczane są na finansowanie jego zadań określonych w ustawie. Wszelkie nadwyżki pieniężne przekazywane są do budżetu państwa. Agencja zobowiązana jest również do dokonywania wpłat oznaczonych kwot z obligacji restrukturyzacyjnych do budżetu państwa na poczet zmniejszenia jej zadłużenia. Ustawa określa przychody i koszty w zakresie gospodarki finansowej Agencji oraz odrębnie te związane z gospodarowaniem mieniem Zasobu. Za zgodą właściwych ministrów Agencja braki we własnym budżecie może wyrównywać poprzez zaciąganie kredytów, emisję własnych obligacji, przy których mienie Zasobu może stanowić ich zabezpieczenie. Agencja ma również prawo odroczyć określony w umowie termin zapłaty należności, rozłożyć na raty lub nawet umorzyć w części lub całości jeżeli przemawiają za tym ważne względy gospodarcze, społeczne czy też losowe. Kwestie te szczegółowo są określane w rozporządzeniu ministra właściwego do spraw rozwoju wsi.

${ }^{38}$ Nieruchomości pozostające w ZWRSP mogą zostać przekazane Lasom Państwowym, jednostce samorządu terytorialnego, Polskiej Akademii Nauk, izbie rolniczej, Krajowej Radzie Izb Rolniczych, państwowej szkole wyższej lub państwowej jednostce badawczo-rozwojowej oraz osobom bezrobotnym bez prawa do zasiłku jeżeli spełniają określone warunki. Agencja może również nieodpłatnie przekazać na rzecz jednostek państwowych i komunalnych określone grunty, urządzenia i sieci energetyczne, wodociagowe, ciepłownicze i telekomunikacyjne. Grunty wchodzące w skład Zasobu, przeznaczone na drogi krajowe, nieodpłatnie stają się drogą decyzji wojewody przedmiotem trwałego zarządu Generalnej Dyrekcji Dróg Krajowych i Autostrad. Prezes Agencji na wniosek ministra właściwego do spraw rozwoju wsi w porozumieniu z ministrem właściwym do spraw gospodarki, może nieodpłatnie przekazać nieruchomości zaliczane do Zasobu na własność zarządzającemu specjalną strefą ekonomiczną. Kwestie te reguluje ustawa z dnia 20 października 1994 r. o specjalnych strefach ekonomicznych (Dz. U. 2007, Nr 42, poz. 274).

${ }^{39}$ Poszczególni potencjalni nabywcy, aby skorzystać z prawa pierwszeństwa zakupu muszą spełniać określone warunki. Wyłączone są też z niego pewne szczegółowo określone w ustawie nieruchomości objęte przepisami innych aktów prawnych. Agencja jest zobligowana do pisemnego zawiadomienia wymienionych uprzednio osób, którym przysługuje pierwszeństwo nabycia nieruchomości, podając cenę nieruchomości oraz termin złożenia wniosku o nabycie na zasadach zawartych w zawiadomieniu. Nieruchomości, które nie zostały na tych zasadach sprzedane lub 
Agencja ma także prawo wprowadzić ograniczenia, co do osób, które mogą wziąć udział w przetargach, tzn. że może zastrzec, iż mogą w nich uczestniczyć potencjalni nabywcy tylko z następujących grup:

— osoby fizyczne spełniające warunki określone w przepisach o kształtowaniu ustroju rolnego, zamierzające powiększyć lub utworzyć gospodarstwo rodzinne, które są:

— rolnikami posiadającymi gospodarstwo rolne w gminie, na obszarze której położona jest nieruchomość oraz zamierzającymi je powiększyć lub

- pracownikami zlikwidowanych państwowych przedsiębiorstw gospodarki rolnej pragnącymi utworzyć gospodarstwo rolne lub

- rolnikami, którzy po 31 grudnia 1991 roku sprzedali Skarbowi Państwa nieruchomości niezbędne na cele publiczne lub

— członkami rolniczych spółdzielni produkcyjnych postawionych w stan likwidacji lub upadłości;

— osoby spełniające warunki do objęcia programem osadnictwa rolniczego;

— repatrianci przybyli do Polski nie wcześniej niż 6 lat przed dniem przetargu;

- spółki utworzone przez pracowników zlikwidowanych państwowych przedsiębiorstw gospodarki rolnej.

Ustawa określa także zasady co do ustalenia ceny sprzedawanej nieruchomości ${ }^{40}$. Agencji przysługuje prawo nabywania nieruchomości na własność Skarbu Państwa, jeżeli jest to podyktowane koniecznością realizacji zadań określonych w ustawie, a w szczególności tych w zakresie powiększania już istniejących gospodarstw rodzinnych. Ponadto daje możliwość nabywania nieruchomości rolnych na rzecz Skarbu Państwa przez państwowe jednostki organizacyjne pod warunkiem, że wymagają tego realizowane przez nie zadania statutowe. Pozostają one wówczas w ich zarządzie na czas nieokreślony.

Ustawa z dnia 11 kwietnia 2003 roku, która weszła w życie z dniem 16 lipca 2003 roku jest aktualnie głównym aktem prawnym regulującym kwestie agrarne w Polsce. Jak twierdzi Wacław Szarliński ustawa ta ...zmodyfikowała dotychczasowa prywatyzacyjno-socjalnq misje

takie, co do których przepisy te się nie odnoszą, podlegają sprzedaży w trybie publicznego przetargu ustnego tj. licytacji. W uzasadnionych gospodarczo przypadkach, przepisy dają również możliwość wyłonienia nabywcy w trybie przetargu pisemnego lub konkursu ofert. W przypadku złożenia ofert równorzędnych, pierwszeństwo przysługuje osobie podlegającej przepisom o ubezpieczeniu społecznym rolników, a także pracownikowi oraz spółce pracowników zlikwidowanego państwowego przedsiębiorstwa gospodarki rolnej, jeśli nabywają nieruchomość w celu powiększenia lub utworzenia gospodarstwa rolnego. W przypadku gdy pierwszeństwo nadal przysługuje kilku nabywcom, wybiera się spośród nich tego, który daje najlepszą gwarancję należytego prowadzenia działalności rolniczej. W przypadku nierozstrzygnięcia przetargu, Agencja może ogłosić kolejny, obniżając cenę do stawki określonej przepisami. Cena ta nie może być niższa niż połowa ceny ustalonej według zasad określonych w przepisach art. 30 analizowanej ustawy. Po następnym, który również nie wyłoni nabywcy, Agencja może sprzedać nieruchomość bez przetargu za cenę nie mniejszą niż cena wywoławcza poprzedniego przetargu.

${ }^{40}$ Poza wytycznymi zawartymi w ustawie, szczegóły w zakresie m.in. trybu sprzedaży nieruchomości Zasobu i warunków rozkładania kwoty zobowiązania na raty regulowane są stosownymi rozporządzeniami ministra właściwego do spraw rozwoju wsi. Por. Rozporządzenie Ministra Rolnictwa i Rozwoju Wsi z dnia 19 listopada 2009 r. w sprawie szczegółowych przesłanek odroczenia, rozłożenia na raty lub umorzenia należności Agencji Nieruchomości Rolnych oraz trybu postępowania w tych sprawach (Dz. U. 2009, Nr 210, poz. 1619), Rozporządzenie Ministra Rolnictwa i Rozwoju Wsi z dnia 17 lutego 2010 r. w sprawie szczegółowego trybu sprzedaży nieruchomości Zasobu Własności Rolnej Skarbu Państwa i ich części składowych, warunków rozkładania ceny sprzedaży na raty oraz stawek szacunkowych gruntów (Dz. U. 2010, Nr 29, poz. 151), Rozporządzenie Ministra Rolnictwa i Rozwoju Wsi z dnia 5 lutego 2010 r. w sprawie wysokości oprocentowania odroczonej lub rozłożonej na raty należności z tytułu sprzedaży mienia z Zasobu Własności Rolnej Skarbu Państwa oraz ustalenia innych niż pieniądz mierników wartości należności pieniężnej (Dz. U. 2010, Nr 23, poz. 118). 
Agencji, zwiększajac zakres zadań zwiazanych z poprawa struktury obszarowej gospodarstw rolnych ${ }^{41}$. Na jej mocy Agencja Nieruchomości Rolnych ma realizować następujące cele:

— poprawę struktury obszarowej rodzinnych gospodarstw rolnych;

- przeciwdziałanie nadmiernej koncentracji nieruchomości rolnych poprzez ograniczenie maksymalnego areału gospodarstwa rodzinnego do 300 ha użytków rolnych;

— zaostrzenie kryteriów dotyczących odpowiednich kwalifikacji i właściwego stażu pracy rolników indywidualnych w gospodarstwach rolnych.

Ustawa realizuje postanowienia art. 23 Konstytucji Rzeczpospolitej Polskiej, zgodnie z którym podstawą polskiego ustroju rolnego jest gospodarstwo rodzinne. Rolnictwo polskie nadal w wielu obszarach nie jest konkurencyjne w porównaniu do zachodnioeuropejskich krajów Unii Europejskiej. W celu przyspieszenia zmian w zakresie struktury rolnej, niezbędne jest włączenie do tego procesu gruntów będących w gestii państwa, które powinny służyć powiększaniu gospodarstw rodzinnych. Ustawa daje Agencji instrumenty, dzięki którym sprawnie może kontrolować obrót nieruchomościami, jak również zainterweniować w razie potrzeby, korzystając z prawa pierwokupu lub wykupu ${ }^{42}$. Pierwsze z nich polega na tym, że w określonych w ustawie przypadkach, ANR może wejść w miejsce nabywcy i zakupić daną nieruchomość rolną za cenę i na warunkach ustalonych uprzednio przez sprzedającego i nabywcę. Prawo wykupu zaś dotyczy umów przenoszenia własności, innych niż umowa sprzedaży ${ }^{43}$, dając Agencji możliwość nabycia nieruchomości rolnej w przypadku m.in. darowizn, wnoszenia nieruchomości rolnych aportem do spółki prawa handlowego, umów działowych, zamiany nieruchomości. Ważnym jest, iż ANR nie ma obowiązku wcześniejszego informowania stron o zamiarze skorzystania $z$ tych uprawnień ${ }^{44}$. Nie oznacza to jednak pozbawienia dzierżawcy prawa pierwokupu nieruchomości rolnej. W miejsce skreślonych w Kodeksie cywilnym przepisów regulujących tę kwestię, ustawa wprowadza nowe rozwiązania. W przy-

${ }^{41}$ W. Szarliński, Realizacja ustawy, „Nowe Życie Gospodarcze” 2007.

${ }^{42} \mathrm{Na}$ mocy ustawy oraz porozumienia zawartego pomiędzy prezesem ANR i Krajową Izbą Notarialną, notariusze są obowiązani poinformować oddziały terenowe i filie Agencji, o zamiarze zawarcia umowy przenoszenia własności nieruchomości rolnych, w stosunku do których przysługuje jej prawo pierwokupu lub wykupu. Następnie Agencja, mając na uwadze powierzone jej ustawą cele, w szczególności zaś kwestię powiększania gospodarstw rodzinnych, dokonuje oceny na ile uzasadnione jest skorzystanie z przysługujących jej praw. Szczegółowe wytyczne w sprawie nabywania nieruchomości do Zasobu WRSP, w tym realizacji przez Agencję prawa pierwokupu i wykupu, zawarte są w załączniku nr 1 do stosownego zarządzenia prezesa ANR, wedle którego do wszelkich czynności prawnych, jak i faktycznych w tym zakresie, na mocy pełnomocnictwa prezesa, uprawnieni są dyrektorzy poszczególnych oddziałów terenowych. Patrz szerzej: Zarządzenie Prezesa Agencji Nieruchomości Rolnych nr 33/08 z dnia 5 sierpnia 2008 r. w sprawie realizacji przez oddziały terenowe ANR prawa pierwokupu i prawa nabycia określonych w ustawie z dnia 11 kwietnia 2003 r. o kształtowaniu ustroju rolnego.

${ }^{43}$ Prawo wykupu nazywane jest też prawem nabycia - oba pojęcia używane są zamiennie. Patrz szerzej: T. Ciodyk, T. Zagórski, P. Iwaszkiewicz, Ustawa o ksztaltowaniu ustroju rolnego w praktyce, w: S. Prutis, B. Wierzbowski (red.), ,Studia Iuridica Agraria”, tom IV, Temida 2, Białystok 2005, s. 143-154.

${ }^{44}$ Z uwagi na statutową działalność ANR, główną przesłanką nabywania przez nią nieruchomości rolnych, jest ich późniejsze udostępnianie rolnikom indywidualnym prowadzącym gospodarstwa rodzinne. Popyt z ich strony na ziemię rolniczą na danym terenie jest niewątpliwie silną podstawą skorzystania przez Agencję ze swych ustawowych uprawnień. Decyzję w tym względzie podejmuje dyrektor oddziału terenowego w oparciu o analizę celowości nabycia nieruchomości. Zasadność skorzystania z tych praw oceniana jest na podstawie m.in. opinii gmin, izb rolniczych, sołtysa oraz dokumentów wewnętrznych. Opinie te nie są jednak wiążące dla ANR, w związku z czym ich brak czy też negatywna ocena planowanych działań, nie przesądza o braku możliwości nabycia nieruchomości przez Agencję w drodze skorzystania z prawa pierwokupu czy też wykupu. Analizie poddawany jest szczegółowo akt notarialny planowanej transakcji, w pierwszej kolejności pod względem jej znaczenia dla realizacji celów ustawy, a następnie w obszarze informacji dotyczących nabywcy, jego gospodarstwa, a także lokalnego rynku ziemi rolnej i skali popytu na nią na danym terenie. Pod uwagę są brane także kwestie obciążeń nieruchomości oraz ograniczeń w jej rolniczym użytkowaniu. 
padku sprzedaży nieruchomości rolnej przez osobę fizyczną lub prawną inną niż ANR, prawo pierwokupu na mocy ustawy przysługuje dzierżawcy, pod pewnymi jednak warunkami ${ }^{45}$. Jak uważa Mirosława Kozłowska-Burdziak można stwierdzić, choć ustawa tego nie precyzuje, że prawo pierwokupu jest narzędziem służacym poprawie struktury obszarowej i równocześnie jest narzędziem ograniczajacym sprzedaż ziemi obcokrajowcom ${ }^{46}$. Nieco innego zdania jest Stanisław Prutis, który podkreśla doniosłość realizacji w głównej mierze tego drugiego celu. Ustawodawca powierzył ANR prawo kontroli, a zarazem ingerencji we wszelkie transakcje obrotu nieruchomościami rolnymi na terenie całego kraju, z czego wnioskować można, że głównym celem ustawy jest przede wszystkim ochrona nieruchomości przed wykupem przez obcokrajowców, nie zaś jedynie zadeklarowane w jej art. 1 kształtowanie ustroju rolnego 47 . Podobny pogląd wyraził również Aleksander Lichorowicz, który stwierdził, że kończqce się w 2002 r. negocjacje z UE uświadomity zwłaszcza stronnictwom ludowym, że klauzula narodowego traktowania przysługujaca po naszym wstapieniu do Unii obywatelom innych krajów członkowskich, w sytuacji gdy w Polsce praktycznie nie istnieje prawna kontrola nabywania gruntów rolnych, spowoduje duża łatwość nabywania gruntów przez cudzoziemców - obywateli UE. Chcac temu zapobiec należało możliwie rychto wprowadzić kontrole nabywania gruntów rolnych przez obywateli polskich, by móc ja stosować także wobec obywateli Unii. I ten cel jest rzeczywistym celem ustawy z 11 kwietnia $2003 r^{48}$ Jak wykazuje Stanisław Prutis, za trafnością takiej oceny przemawia sama konstrukcja ustawy, wedle której prawo pierwokupu i wykupu przysługuje Agencji w stosunku do każdej umowy skutkującej nabyciem własności nieruchomości rolnej tak przez Polaka, jak i obcokrajowca. Ustawa przewiduje pewne odstępstwa od tej uniwersalnej zasady. Nie przysługuje ANR prawo pierwokupu i wykupu, gdy transakcja kupna-sprzedaży nieruchomości rolnej zachodzi między osobami bliskimi w myśl przepisów o gospodarce nieruchomościami ${ }^{49}$, a także gdy w jej wyniku następuje powiększenie gospodarstwa rodzinnego do powierzchni nieprzekraczającej 300 ha, nieruchomość zaś położona jest w gminie zamieszkania nabywcy lub sąsiadującej. Wyłączenie obrotu rodzinnego i sąsiedzkiego z możliwości agencyjnej ingerencji przemawia za stwierdzeniem, że głównym celem ustawy była ochrona przed wykupem ziemi rolniczej przez obcokrajowców, gdyż tego typu transakcje dominują w ogóle czynności związanych z obrotem nieruchomościami rolnymi. Stąd też nasuwa się wniosek, że deklarowane w ustawie zasady kształtowania ustroju rolnego w krajowym obrocie ziemią prywatną, zeszły na dalszy plan. Przyznane zaś Agencji prawa do pierwokupu i wykupu, są w ocenie Stanisława

\footnotetext{
${ }^{45}$ Dzierżawca może skorzystać z prawa pierwokupu, jeżeli umowa dzierżawy została zawarta w formie pisemnej, ma pewną datę - poświadczoną urzędowo, była wykonywana co najmniej 3 lata, licząc od daty jej zawarcia, a nabywana nieruchomość wchodzi w skład gospodarstwa rodzinnego dzierżawcy lub jest dzierżawiona przez spółdzielnię produkcji rolnej. Dzierżawcy nie przysługuje zaś prawo pierwokupu w dwóch wypadkach, tj. jeżeli w myśl przepisów o gospodarce nieruchomościami, nabywca jest osoba bliska zbywcy lub jeżeli dzierżawiona nieruchomość nie wchodzi w skład gospodarstwa rodzinnego.

${ }^{46}$ M. Kozłowska-Burdziak, Rola Agencji Nieruchomości Rolnych w obrocie ziemiq rolnicza, SGGW, Prace naukowe nr 38.

${ }^{47}$ S. Prutis, Ksztaltowanie ustroju rolnego-potrzeba nowej regulacji ustawowej, w: S. Prutis (red.), ,Studia Iuridica Agraria”, tom V, Temida 2, Białystok 2005, s. 170.

48 A. Lichorowicz, Regulacja obrotu gruntami rolnymi wedtug ustawy z 11 IV 2003 r. o ksztaltowaniu ustroju rolnego na tle ustawodawstwa agrarnego Europy Zachodniej, „Przegląd Legislacyjny” nr 3/2004, przedruk: „Studia Iuridica Agraria", tom IV, s. 28.

${ }^{49}$ W myśl ustawy z dnia 21 sierpnia 1997 r. o gospodarce nieruchomościami (Dz. U. 2004, Nr 261, poz. 2603, ze zm.) za osobę bliską zbywcy uznaje się zstępnych, wstępnych, rodzeństwo, dzieci rodzeństwa, małżonka, osoby przysposabiające i przysposobione oraz osobę, która pozostaje ze zbywcą faktycznie we wspólnym pożyciu (art. 4, pkt 13).
} 
Prutisa adekwatnymi narzędziami służącymi tylko jednemu, deklarowanemu w art. 1 ustawy celowi, tj. przeciwdziałaniu nadmiernej koncentracji nieruchomości rolnych ${ }^{50}$. Aleksander Lichorowicz wskazuje zaś, że nawet w tej dziedzinie powierzone Agencji uprawnienia mają charakter pośredni. Nabyte grunty rolne, za sprawą których powierzchnia gospodarstwa rolnego przekroczy 300 ha, na skutek czego utraci status gospodarstwa rodzinnego, podlegają prawu pierwokupu i wykupu. Dopóki jednak ANR nie podejmie środków zmierzających do wykorzystania powierzonych jej uprawnień, taka transakcja pozostaje ważna nawet jeżeli dotyczy poważnych obszarów gruntów rolnych. Innymi słowy transakcja zmierzająca do koncentracji nawet kilkuset hektarów gruntów nie podlega kontroli i nie wymaga zgody żadnego organu państwowego. Jedynym zagrożeniem dla tego typu działań jest zastosowanie post factum wielokrotnie już wspominanych uprawnień ANR, które, o czym należy pamiętać, uzależnione są także od ilości posiadanych przez nią środków finansowych ${ }^{51}$.

Ustawa oprócz zagadnień obrotu gruntami rolnymi wprowadza nowe definicje, precyzujące podstawowe kwestie w niej poruszone. Na uwagę zasługują: gospodarstwo rolne, rolnik indywidualny, kwalifikacje rolnicze. Za gospodarstwo rodzinne ustawodawca uznaje gospodarstwo rolne o powierzchni nie mniejszej niż 1 ha, prowadzone przez rolnika indywidualnego, w którym łączna powierzchnia użytków rolnych (czyli własnych oraz dzierżawionych) nie przekracza 300 ha. Warto zauważyć, że nie bierze się pod uwagę innych tytułów prawnych jak np. użytkowanie. Do tej pory funkcjonujące w Konstytucji RP z 1997 roku pojęcie pozostawało niesprecyzowane. Ustawa definiuje również pojęcie rolnika indywidualnego, za którego uznaje się osobę fizyczną, która jest właścicielem lub dzierżawcą nieruchomości rolnych o łącznej powierzchni nieprzekraczającej 300 ha (niezależnie ile ma ona gospodarstw i gdzie są położone). Warunkiem koniecznym jest również osobiste prowadzenie gospodarstwa rolnego ${ }^{52}$. Posiadać musi także odpowiednie kwalifikacje rolnicze oraz mieszkać na terenie gminy, w obszarze której znajduje się przynajmniej jedna z nieruchomości rolnych wchodzących w skład gospodarstwa rolnego. Doprecyzowana została również definicja kwalifikacji rolniczych, które zgodnie z ustawą posiada osoba fizyczna mająca odpowiednie przygotowanie teoretyczne lub praktyczne do prowadzenia działalności rolniczej ${ }^{53}$. Aleksander Lichorowicz krytycznie odniósł się do tych regulacji, gdyż jak zauważył wymóg posiadania kwalifikacji rolniczych nie stanowi warunku koniecznego ważności transakcji nabycia nieruchomości rolnej, a jedyną konsekwencją ich nieposiadania jest brak statusu rolnika indywidualnego, zaś gospodarstwo nie jest uznawane za rodzinne. W konsekwencji ANR może skorzystać z prawa pierwokupu lub wykupu. Tego typu rozwiązanie w zasadniczy sposób odróżnia polskie przepisy od stosowanych w większości krajów Europy Zachodniej. Ponadto mocą ustawy nie wprowadzono żadnego trybu sprawdzania deklarowanych kwalifikacji rolniczych nabywcy. Co więcej przepis zrównujący wykształcenie rolnicze z jakimkolwiek wykształceniem średnim lub wyższym jest rozwiązaniem niespotykanym w skali europejskiej i jak się wydaje niesłusznym, gdyż nie gwarantuje znajomości zasad prowadzenia prawidłowej gospodarki rolnej ${ }^{54}$.

${ }^{50}$ S. Prutis, Ksztaltowanie ustroju rolnego..., op. cit., s. 171-182.

51 A. Lichorowicz, Regulacja obrotu gruntami rolnymi wedtug ustawy z 11 IV 2003 r. ..., op. cit., s. 15-18.

${ }^{52}$ Pod tym pojęciem rozumie się podejmowanie wszelkich decyzji w zakresie zarządzania działalnością rolniczą, czyli działalnością wytwórczą w zakresie produkcji roślinnej (także sadowniczej, ogrodniczej) lub zwierzęcej (w tym rybnej).

${ }^{53}$ Przygotowanie teoretyczne obejmuje wykształcenie rolnicze co najmniej na poziomie zasadniczej szkoły zawodowej lub wykształcenie średnie albo wyższe w jakimkolwiek zakresie. Jako kwalifikacje praktyczne uznaje się co najmniej 5-letni okres samodzielnego prowadzenia lub stażu pracy w gospodarstwie rolnym.

${ }^{54}$ A. Lichorowicz, Regulacja obrotu gruntami rolnymi wedlug ustawy z 11 IV 2003 r. ..., op. cit., s. 18-19. 
Ustawa z dnia 11 kwietnie 2003 roku o kształtowaniu ustroju rolnego wprowadziła pewne zmiany do ustawy z dnia 19 października 1991 r. o gospodarowaniu nieruchomościami rolnymi regulującej m.in. zasady sprzedaży nieruchomości Zasobu. Obecnie nabywca może zakupić nieruchomość pod warunkiem, iż w wyniku transakcji łączna powierzchnia użytków rolnych będących w jego posiadaniu nie przekroczy 500 ha. Wprowadzono również przepis, wedle którego Agencja może odkupić uprzednio nabytą nieruchomość w okresie 5 lat, licząc od dnia jej nabycia od ANR za zwrotem ceny i kosztów sprzedaży oraz koniecznych nakładów jeżeli zwiększyły one wartość nieruchomości, z ujawnieniem tego prawa w księdze wieczystej ${ }^{55}$.

Już w dwa lata od wejścia w życie ustawy z dnia 11 kwietnia 2003 r. o kształtowaniu ustroju rolnego spotkała się ona z szeregiem krytyki. Stanisław Prutis twierdzi, iż zastosowane $\mathrm{w}$ ustawie rozwiązania prawne nie gwarantują realizacji deklarowanych w jej art. 1 zasad aktywnej roli prawa w kształtowaniu ustroju rolnego. Wyraża przekonanie, że została ona błędnie skonstruowana, gdyż podstawowe instrumenty mające, w zamiarze ustawodawcy pozytywnie wpływać na kształt ustroju, nie spełniają swej roli. Jak wykazuje, z danych Agencji Nieruchomości Rolnych, której owe mechanizmy zostały powierzone, wynika, że zastosowanie prawa pierwokupu i wykupu w niewielkim tylko stopniu wpływają na zmiany struktury agrarnej. Co więcej pozostawiona Agencji pewna swoboda czy też uznaniowość w stosowaniu tych narzędzi interwencji, stanowić może zagrożenie dla zasady bezpieczeństwa obrotu nieruchomościami rolnymi. Jako że Agencja może, jednak nie ma obowiązku korzystania z przysługujących jej praw, stąd też te uprawnienia mogą być wykorzystywane dla realizacji jej własnych celów ${ }^{56}$.

Samo prawo pierwokupu dzierżawcy nie budzi - jak wskazuje Stanisław Prutis - zastrzeżeń i stanowi adekwatne narzędzie poprawy struktury agrarnej gospodarstw. Wykazuje, że w istotny sposób wpływa na zachowanie przez producenta rolnego ciagłości produkcyjnej. Ten sam instrument, a także prawo wykupu wykorzystywane przez ANR budzi natomiast już pewne zastrzeżenia. Jako że korzystając z prawa pierwokupu lub wykupu, Agencja włącza nabyte nieruchomości do Zasobu Własności Rolnej Skarbu Państwa, którymi dysponuje wedle własnych programów, trudno stąd jednoznacznie wnioskować, że nabyte tą drogą grunty zostaną bezwzględnie wykorzystane w celach poprawy struktury obszarowej, choć oczywiście istnieje taka możliwość. Poddając te przepisy krytyce, Stanisław Prutis podkreśla, że brakuje w nich bezpośredniego związku między zastosowaniem przysługujących Agencji praw a poprawą struktury obszarowej konkretnego gospodarstwa rodzinnego. Postuluje tym samym przyznanie prawa pierwokupu potencjalnym nabywcom nieruchomości - sąsiadom lub bliskim zbywcy, twierdząc iż w obrocie rodzinnym lub też lokalnym taki mechanizm z pewnością byłby skuteczniejszym narzędziem poprawy struktury agrarnej ${ }^{57}$.

Najnowsze zmiany w zakresie ustroju rolnego wprowadzone zostały ustawą o zmianie ustawy o kształtowaniu ustroju rolnego z dnia 6 maja 2010 r. ${ }^{58}$ Dotyczą one ograniczenia prawa pierwokupu nieruchomości rolnych w obszarze do 5 ha, przysługujące dotychczas Agencji

\footnotetext{
55 Wyjątek stanowią nieruchomości położone w granicach specjalnych stref ekonomicznych. Przepis ten zgodnie z wyrokiem Trybunału Konstytucyjnego z 18 marca 2010 r. (sygn. akt K 8/08, Dz. U. 2010, Nr 48, poz. 287) został uznany za niezgodny z Konstytucją. Trybunał Konstytucyjny uznał, że tego typu działania stanowią nieproporcjonalną ingerencję w konstytucyjnie chronione prawo własności (art. 21 ust. 1 i art. 64 Konstytucji RP). Z dniem ogłoszenia wyroku wykonywanie przez Agencję prawa odkupu jest niemożliwe.

${ }^{56}$ S. Prutis, Ksztaltowanie ustroju rolnego..., op. cit., s. 168-169.

${ }^{57}$ S. Prutis, Ksztaltowanie ustroju rolnego..., op. cit., s. 173-174.

${ }^{58}$ Ustawa o zmianie ustawy o kształtowaniu ustroju rolnego z dnia 6 maja 2010 r. (Dz. U 2010, Nr 110, poz. 725$)$.
} 
Nieruchomości Rolnych. Nieruchomości do 5 ha wyłączono także spod działania instytucji nabycia $^{59}$. Zmiany te były podyktowane faktem, iż zdecydowana większość umów przekazywanych do ANR, w stosunku do których przysługuje jej prawo pierwokupu i nabycia, dotyczy nieruchomości rolnych niewielkich obszarowo ${ }^{60}$. Takie nieruchomości mimo, iż potencjalnie mogą służyć do celów nierolniczych, to ze względu na brak miejscowych planów zagospodarowania traktowane są przez notariuszy jako nieruchomości rolnicze i umowy ich dotyczące kierowane są do rozpatrzenia przez Agencję. Faktycznie zaś nie mają one większego znaczenia $\mathrm{w}$ realizacji jej ustawowego zadania, tj. poprawy struktury agrarnej i choć z formalnego punktu widzenia są nieruchomościami rolnymi, to jednak najczęściej nadają się pod zabudowę. Stąd też zmiany te mają ograniczyć konieczność angażowania się ANR w czysto biurokratyczne czynności w odniesieniu do tych niewielkich nieruchomości, które w praktyce nie są przez nią nabywane. Ponadto docelowo mają przyczynić się usprawnieniom w ich obrocie poprzez skrócenie czasu przenoszenia własności oraz zwiększeniu podaży gruntów pod budownictwo. Rozwiązanie to zostało pozytywnie ocenione przez prezesa zarządu Federacji Związków Pracodawców - Dzierżawców i Właścicieli Rolnych - Leszka Derezińskiego. Uznał on, iż dotychczasowe rozwiqzania przynosity pieniadze notariuszom, a dla rolników kupujacych działki stwarzały problemy i generowaty niepotrzebne koszty ${ }^{61}$. W związku z powyższym, ANR będzie mogła poświęcić więcej czasu i energii na obsługę obrotu większymi nieruchomościami, które mają realne znaczenie w poprawie struktury obszarowej gospodarstw rolnych w szczególności rodzinnych ${ }^{62}$.

Kształtowanie ustroju rolnego jest procesem, znajomość zaś rozwiązań istniejących w innych krajach może stanowić inspirację do kolejnych zmian w naszym kraju zmierzających w kierunku poprawy struktury obszarowej gospodarstw. W Polsce, państwową jednostką

\footnotetext{
${ }^{59}$ Początkowo ograniczenie to dotyczyło nieruchomości do 1 ha, jednakże z uwagi na względy praktyczne pułap ten zwiększono do 5 ha na mocy przepisów ustawy z dnia 6 maja 2010 r. o zmianie ustawy o kształtowaniu ustroju rolnego (Dz. U. 2010, nr 110, poz. 725).

${ }^{60}$ Do Sejmu skierowane zostały dwa projekty dotyczące kształtowania ustroju rolnego: Komisyjny projekt ustawy o zmianie ustawy o ksztaltowaniu ustroju rolnego (druk sejmowy 1053), który wpłyną1 8.08.2008 r. oraz Senacki projekt ustawy o zmianie ustawy o kształtowaniu ustroju rolnego (druk sejmowy 1745), który wpłynął 6.02.2009 r. Oba projekty rozpatrywane były wspólnie. W Opinii merytorycznej do senackiego projektu ustawy o zmianie ustawy o ksztaltowaniu ustroju rolnego wskazano, iż od początku obowiązywania ustawy o kształtowaniu ustroju rolnego do końca września 2008 r. do ANR wpłynęło 487 tys. aktów notarialnych dotyczących przeniesienia własności nieruchomości. Zdecydowana ich większość, bo aż 78\% (ok. 380 tys. umów) dotyczyło nieruchomości rolnych poniżej 1 ha. Patrz szerzej: D. Stankiewicz, Opinia merytoryczna do senackiego projektu ustawy o zmianie ustawy o ksztaltowaniu ustroju rolnego, Warszawa, 26 marca $2009 \mathrm{r}$.

${ }^{61}$ D. Stojak, Agencja nie wykupi dziatek rolniczych mniejszych niż 5 ha, „Dziennik Gazeta Prawna”, nr 131 (2762), 8 lipca 2010, s. B7.

${ }^{62} \mathrm{Za}$ przesłankę wprowadzenia tych zmian posłużyły także wysokie koszty, jakie Agencja musiała ponosić w związku z koniecznością wszczynania stosownych procedur. O ich wadze świadczyć może fakt, iż podobne propozycje, tj. wprowadzenie ograniczeń Agencji w stosunku do nieruchomości nieprzekraczającej 1 ha, prezentowane były w kilku dokumentach: Poselskim projekcie ustawy o zmianie ustawy o kształtowaniu ustroju rolnego oraz o zmianie niektórych ustaw (druk sejmowy $\mathrm{nr} 687$ z 30 listopada 2007 r.), Komisyjnym projekcie ustawy o zmianie ustawy o kształtowaniu ustroju rolnego (druk sejmowy nr 1053 z 8 sierpnia 2008 r.), Senackim projekcie ustawy o zmianie ustawy o ksztaltowaniu ustroju rolnego (druk sejmowy 1745 z 6 lutego 2009 r.). Początkowo oba, wspólnie rozpatrywane projekty (komisyjny i senacki) odnosiły się do nieruchomości do 1 ha. W drugim czytaniu poseł reprezentujący Klub Parlamentarny Lewica zgłosił poprawkę, aby zmiany te dotyczyły nieruchomości o powierzchni nie większej niż 5 ha, która została ostatecznie przyjęta.
} 
powołaną do kształtowania struktury agrarnej jest Agencja Nieruchomości Rolnych. Jednym z głównych jej zadań jest ochrona i wzmacnianie gospodarstw rodzinnych. W jej gestii pozostaje także gospodarowanie mieniem Zasobu WRSP, w którym nadal znajduje się 2212,5 tys. ha. Nierównomierne w skali kraju rozmieszczenie gruntów Zasobu jest niewątpliwie czynnikiem niekorzystnym z punktu widzenia pozytywnych zmian obszarowych gospodarstw rodzinnych. Ponadto nieunormowany status prawny wielu działek uniemożliwia trwałe ich zagospodarowanie, a w szczególności sprzedaż. Agencja posiada jednak możliwość ingerencji w prywatne transakcje dotyczące obroty gruntami rolnymi. Te uprawnienia z założenia zostały jej przyznane w celu kreowania pozytywnych przemian agrarnych. Na tle rozwiązań stosowanych w analizowanych państwach, tj. Francji, Niemczech i Danii, polskie prawodawstwo nie jest szczególnie restrykcyjne. Bardziej ograniczające np. w kwestiach obszarowych są przepisy duńskie, wedle których łączna powierzchnia gospodarstwa rolnego nie może przekroczyć 70 ha. Niezwykle zasadnicze są też w pewnych obszarach normy niemieckie, zastrzegające niepodzielność gospodarstwa rolnego w trakcie działów spadkowych. Ustawodawstwo francuskie zaś jest oceniane jako najbardziej zaawansowane na poziomie legislacyjnym. Zauważyć jednak można także punkty styczne, takie jak chociażby uwypuklenie konieczności posiadania przez rolników kwalifikacji rolniczych. Niewątpliwie polskie prawo dotyczące struktury obszarowej wymaga jeszcze na wielu polach dopracowania i zmian. Niezależnie od głosów krytycznych, za potrzebną próbę regulacji kwestii agrarnych, należy uznać ustawę z 11 kwietna 2003 r. o kształtowaniu ustroju rolnego. Pozytywnie należy także ocenić zmiany wprowadzone ustawą o zmianie ustawy o kształtowaniu ustroju rolnego z dnia 6 maja 2010 r. Ponadto pewne przeobrażenia zaszły także na poziomie funkcjonowania Agencji Nieruchomości Rolnych. Podstawową formą zagospodarowania mienia Zasobu WRSP, zgodnie z nowymi wytycznymi, ma być sprzedaż. Uwzględniając trudności w realizacji tego celu (np. roszczenia reprywatyzacyjne) kierunek ten należy uznać za słuszny. Tak zdecydowane włączenie gruntów państwowych do obrotu nieruchomościami rolnymi daje podstawy przypuszczać, iż tempo przemian agrarnych będzie w przyszłości znacznie szybsze niż dotąd, co powinno wyraźnie zbliżyć naszą strukturę rolnictwa do krajów wysokorozwiniętych.

\section{Summary}

Agriculture is a peculiar sector of the economy that requires support from the state. Its spontaneous transformation is not effective enough, therefore a number of mechanisms are applied to stimulate advantageous structural transformation both at EU and national levels. The agricultural system of West European states is based on the family farm. Although Community law does not define a family farm, different systems provide various measures applied in order to protect family farms, e.g. by means of controlling agricultural land trade. The paper presents the legal and institutional solutions applied in this respect in France, Germany and Denmark. These states have not been randomly selected, as they are the main competitors for Polish agriculture in the Community market, and they have succeeded in establishing an agrarian structure. Against the background of their experience, Polish legal solutions are presented and assessed. The responsibilities of the Agricultural Property Agency are presented in detail; its principal task apart from the management of State Treasury property is to shape agrarian structure. 